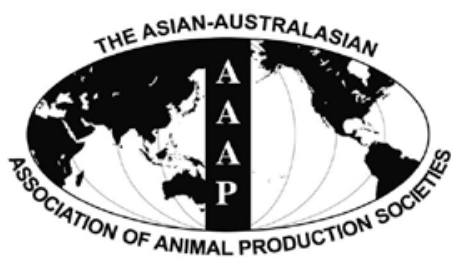

Asian-Aust. J. Anim. Sci.

Vol. 25, No. 1 : 92 - 97

January 2012

www.ajas.info

http://dx.doi.org/10.5713/ajas.2011.11175

\title{
Effect of Sea Buckthorn Leaves on Inosine Monophosphate and Adenylosuccinatelyase Gene Expression in Broilers during Heat Stress
}

\author{
Wei Zhao, Xin Chen, Changjiang Yan, Hongnan Liu, Zhihong Zhang, Pengzu Wang, Jie Su and Yao Li* \\ Institute of Animal Nutrition, Northeast Agricultural University, Harbin, 150030, China
}

\begin{abstract}
The trial was conducted to evaluate the effects of sea buckthorn leaves (SBL) on meat flavor in broilers during heat stress. A total 360 one-day-old Arbor Acre (AA) broilers (male) were randomly allotted to 4 treatments with 6 replicates pens pretreatment and 15 birds per pen. The control group was fed a basal diet, the experimental group I, II and III were fed the basal diet supplemented with $0.25 \%, 0.5 \%, 1 \% \mathrm{SBL}$, respectively. During the 4 th week, broilers were exposed to heat stress conditions $\left(36 \pm 2^{\circ} \mathrm{C}\right.$ ), after which, muscle and liver samples were collected. High performance liquid chromatography (HPLC) was performed to measure the content of inosine monophosphate (IMP); Real-Time PCR was performed to determine the expression of the ADSL gene. The results showed that the content of breast muscle IMP of group I, II and III was significantly increased 68\%, 102\% and $103 \%$ ( $p<0.01)$ compared with the control, respectively; the content of thigh muscle IMP of group II and III was significantly increased $56 \%$ and $58 \%$ ( $<<0.01$ ), respectively. Additionally, ADSL mRNA expression in group I, II and III was increased significantly $80 \%, 65 \%$ and $49 \%$ (p<0.01) compared with the control, respectively. The content of IMP and expression of ADSL mRNA were increased by basal diet supplemented with SBL, therefore, the decrease of meat flavor caused by heat stress was relieved. (Key Words : Sea Buckthorn Leaf, Heat Stress, Inosine Monophosphate, Adenylosuccinatelyase)
\end{abstract}

\section{INTRODUCTION}

Sea buckthorn (Hippophae rhamnoides) is a small shrub comprised of fruit and leaves that are rich in nutrients and bioactive components such as vitamins (Kudritskaya et al., 1989; Zadernowski et al., 2003; Luhua et al., 2004; Ranjith et al., 2006), amino acids (Yushipitsina et al., 1988; Repyakh et al., 1990), lipids (Goncharova and Glushenkova, 1993; Ul'chenko et al., 1995; Bekker and Giushenkova, 1997), sugars and acids (Yang, 2009), and flavonoids (Häkkinen et al., 1999). Recently studies have shown that sea buckthorn has antioxidant (Geetha et al., 2002a; Geetha et al., 2002b; Chawla et al., 2007; Püssa et al., 2007; Geetha et al., 2009), anticancer (Olsson et al., 2004; Ma et al., 2007; Boivin et al., 2007), antiinfective (Larmo et al., 2008) and exerts beneficial effects on liver fibrosis (Gao et al., 2003) and immune function (Dorhoi et al., 2006). Sea buckthorn decreases the damage of enzyme activity or hormonal metabolic organism status caused by

\footnotetext{
* Corresponding Author : Yao Li. Tel: +86-451-55190093, E-mail: liyao1966@sina.com
}

Received June 3, 2011; Accepted September 20, 2011 immobilization or cold-hypoxia-restraint (Krylova et al., 2000; Saggu and Kumar, 2007), however, its effects on heat stress is unclear. Heat stress is one of the most universal stress factors affecting poultry (Gregory, 2010), and is a major contributor to growth restriction (Liu, 2011; Melesse et al., 2011). In addition, heat stress can also influence the meat quality and flavor of poultry (Miao, 2007; Chiang et al., 2008; Lu et al., 2009).

Muscle inosine monophosphate (IMP) content is an indicator meat flavor and adenylosuccinatelyase (ADSL) is a key enzymes regulating IMP synthesis. Zhang et al. (2006) indicated there was positive correlation between the expression of ADSL gene and muscle IMP content. Therefore, the goal of the current study was to assess the effect of sea buckthorn leaves (SBL) on ADSL gene expression and IMP content were investigated during heat stress in poultry.

\section{MATERIALS AND METHODS}

Experimental birds, diets, and treatment

A total of 360 one-day-old male AA broilers (Harbin 
Delin broiler Co., Harbin, China) were randomly allotted to 4 groups of 90 birds each, with 6 replicates of 15 birds each. SBL that was collected in the Farm 8511 in June (Mishan, China) was shattered into powder with passing 40 screen mesh. The control group was fed a basal diet while the experimental group I, II and III were fed the basal diet supplemented with $0.25 \%, 0.5 \%, 1 \%$ SBL powder, respectively. Small amounts of the basal diet were first mixed with the respective amounts of SBL powder as a small batch and then mixed with a larger amount of the basal diet until the total amounts of the respective diets were homogenously mixed. The basal maize-soybean diet (Table 1) was formulated to refer to the NY/T 33-2004 (Chinese, 2004) and NRC (1994) nutrient requirement. Diets and fresh water were offered ad libitum. During the 4th week (from the 22th day to the 28th day), birds were

Table 1. Composition and nutrient level of basal diet (air-dry basis)

\begin{tabular}{|c|c|c|}
\hline Items & $0-3$ weeks & 4 weeks \\
\hline \multicolumn{3}{|l|}{ Ingredients (\%) } \\
\hline Corn & 60.45 & 63.90 \\
\hline Soybean meal & 32.05 & 28.50 \\
\hline Maize oil & 2.50 & 3.20 \\
\hline Fish meal & 1.10 & 1.10 \\
\hline DL-met & 0.21 & 0.09 \\
\hline Lys & 0.03 & 0.00 \\
\hline $\mathrm{CaHPO}_{4}$ & 1.80 & 1.60 \\
\hline Limestone & 1.33 & 1.13 \\
\hline $\mathrm{NaCl}$ & 0.20 & 0.15 \\
\hline Vitamins premix $^{1}$ & 0.03 & 0.03 \\
\hline Minerals premix ${ }^{2}$ & 0.20 & 0.20 \\
\hline Choline chloride & 0.10 & 0.10 \\
\hline Total $^{4}$ & 100.00 & 100.00 \\
\hline \multicolumn{3}{|l|}{ Nutrient levels $^{3}$} \\
\hline ME (MJ/kg) & 12.56 & 12.96 \\
\hline CP (\%) & 21.53 & 20.01 \\
\hline Lys (\%) & 1.15 & 1.03 \\
\hline Met (\%) & 0.55 & 0.41 \\
\hline Met+cys (\%) & 0.91 & 0.76 \\
\hline Сa (\%) & 0.91 & 0.76 \\
\hline Total P (\%) & 1.02 & 0.90 \\
\hline Available P (\%) & 0.70 & 0.65 \\
\hline \multicolumn{3}{|c|}{$\begin{array}{l}{ }^{1} \text { Provided per kg diet: vitamin } \mathrm{A} \text {, } 8,000 \mathrm{IU} \text {; vitamin } \mathrm{D}_{3}, 1,000 \mathrm{IU} \text {; vitamin } \\
\text { E, } 20 \mathrm{IU} \text {; vitamin } \mathrm{K}, 0.5 \mathrm{mg} \text {; vitamin } \mathrm{B}_{1}, 2.0 \mathrm{mg} \text {; vitamin } \mathrm{B}_{2}, 8 \mathrm{mg} \text {; } \\
\text { vitamin } \mathrm{B}_{12}, 0.01 \mathrm{mg} \text {; bioepiderm, } 0.18 \mathrm{mg} \text {; pantothenic acid, } 10 \mathrm{mg} \text {; } \\
\text { niacin, } 35 \mathrm{mg} \text {; pyridoxine, } 3.5 \mathrm{mg} \text {; folic acid, } 0.55 \mathrm{mg} \text {; choline, } 1,300 \mathrm{mg} \\
\text { supplied by Lovit broiler I complex vitamins (Harbin Lovit animal health } \\
\text { Co., Harbin, China). }\end{array}$} \\
\hline
\end{tabular}

exposed to heat stress at $36 \pm 2^{\circ} \mathrm{C}$ for $12 \mathrm{~h} / \mathrm{d}(06: 00$ to $18: 00)$ and $22^{\circ} \mathrm{C}$ for $12 \mathrm{~h} / \mathrm{d}$ (18:00 to 06:00).

\section{Sampling time and procedures}

At the 29th day, 2 birds per replicate were randomly killed after fasting $12 \mathrm{~h}$. by cervical dislocation. The carcasses were then opened and the left breast and thigh muscle and liver samples were rapidly harvested and stored at $-80^{\circ} \mathrm{C}$ until analysis. The Committee on Animal Care at Northeast Agricultural University approved the animal care procedures employed.

\section{Assay of IMP content}

Assay of IMP content in muscles : One gram of muscle sample was shredded and homogenated two times in chilled $10 \mathrm{ml} 3.5 \% \mathrm{HClO}_{4}$. The resulting homogenate was centrifuged at 3,500×g for $10 \mathrm{~min}$ and the supernatant was collected, the sediment was washed in $5 \mathrm{ml} \mathrm{3.5 \%} \mathrm{HClO}_{4}$, centrifuged and the supernatant collected and combined with the first supernatant. Double distilled water $\left(\mathrm{ddH}_{2} \mathrm{O}\right)$ was added at twice the volume of the supernatant up to 25 $\mathrm{ml}$. The diluted supernatant was pipetted in $1 \mathrm{ml}$ aliquots and $9 \mathrm{ml}$ distilled water was added. Samples were filtered by $0.45 \mu \mathrm{m}$ filter membrane and separated by highperformance liquid chromatography (HPLC) equipped with the 600E Multisolvent Delivery System and a UV 2487 Detector with Empower software (Waters Co., Milford, USA). The chromatographic column was Symmetry Shield $^{\mathrm{TM}}$ RP18 $\left(\mathrm{C}_{18}\right), 5 \mu \mathrm{m}$ (Waters Co., Milford, USA). Mobile phase was phosphate triethyl ammonium and methanol (Sigma Co., USA) (95:5), all reagents were chromatographic pure; the flow rate was $1.0 \mathrm{ml} / \mathrm{min}$; the detection wavelength was $254 \mathrm{~nm}$; the chromatographic column temperature was $25^{\circ} \mathrm{C}$; the sample size was $10 \mu \mathrm{l}$.

Preparation of standard curve : The IMP standard substance (Sigma chemicals, St. Louis, USA) was accurately weighed and then dissolved in the appropriate volume of Mobile phase to produce corresponding standard solutions at six concentrations in the range of 0.25 to 8 $\mu \mathrm{g} / \mathrm{ml}$ (multiproportion). The IMP standard curves were plotted after linear regression of the peak areas versus concentrations.

\section{Assay of gene expression}

Assay of ADSL gene expression in liver : Total RNA was extracted from liver tissue, referring to the method offered by Shanghai Huashun RNArose kit (Huashun biotechnology Co., Shanghai, China). The RNA quality was detected by formaldehyde gel apomorphosis electrophoresis, the RNA concentration and purity was determined by spectrophotometer at $\mathrm{A}_{260} / \mathrm{A}_{280}$, and $2 \mu \mathrm{g}$ total RNA was reverse transcribed into cDNA using $\mathrm{M}-\mathrm{MLV}$ reverse transcriptase (Promega Co., Madison, USA). ADSL primers 
Table 2. Primer sequence, product size and position

\begin{tabular}{llcc}
\hline Gene & Primers & Product/bp & GenBank No. \\
\hline ADSL & F: 5'-TTGGCTCAAGTGCTATGC-3' & 224 bp & EU049886 \\
& R: 5'-TCCCTCGGAGATGTTCTG-3' & & AF173612 \\
18sRNA & F: 5'-TAGATAACCTCGAGCCGATCGCA-3' & 312 bp & \\
& R: 5'-GACTTGCCCTCCAATGGATCCTC-3' & & \\
\hline
\end{tabular}

were synthesized by Shanghai biotechnology Co. (China), referring to the GeneBank cDNA sequence (Table 2), and the reference gene was 18sRNA (Yusuke Matsubara et al., 2005).

Amplicons via 1\% agarose gel electrophoresis (AGE) chosen for sequencing were purified by using a TIANgel Midi Purification Kit (Tiangen biotechnology Co., Beijing, China) prior to sequencing. After purification, the PCR product was sequenced by Shanghai biotechnology Co. (China), and the sequencing primer sets were the same as those used for Real-Time PCR. Target genes were determined by Real-Time PCR after validating the sequence homologies.

Real-Time PCR procedure referred to $\mathrm{SYBR}^{\circledR}$ Premix Ex Taq $^{\mathrm{TM}}$ kit instruction obtained from TaKaRa biotechnology Co. (Dalian, China), and $1 \mu \mathrm{l}$ cDNA template was introduced into the reaction that was carried out in 20 $\mu$ l ABI PRISM 7500 Real-Time PCR Reaction System (Applied Biosystems Co., USA). Temperature cycles were as follows: $95^{\circ} \mathrm{C}$ pre-degeneration $10 \mathrm{~s}, 95^{\circ} \mathrm{C}$ degeneration $5 \mathrm{~s}, 60^{\circ} \mathrm{C}$ renaturation/extension $34 \mathrm{~s}$.

Preparation of amplification efficiency curve : The cDNA was gradient diluted according to Table 3, and various concentrations of cDNA were amplified by RealTime PCR with the primers of ADSL and 18sRNA genes. The reaction system and procedure were in accordance to above. The amplification efficiency curves were plotted after linear regression of the cycle threshold (Ct value) versus $\log _{10}$ diluion . Amplification efficiency $E=10^{-1 / \text { slope }}-1$.

\section{Statistical analyses}

Data was analyzed by using one-factorial ANOVA procedure of SAS 8.0. Statistical significance was assumed at $\mathrm{p}<0.01$. Data were expressed as mean \pm pooled SEM. Replicate was considered as the experimental unit. Number (n) used for statistics is note in the tables.

\section{RESULTS}

\section{Effects of SBL on muscle IMP content in AA broilers}

The effects of SBL on muscle IMP content are summarized in Table 3. Compared with the control, the content of breast muscle IMP of group I, II and III was significantly increased 68, 102, and 103\% ( $<<0.01)$, respectively; the content of thigh muscle IMP of group II and III was significantly increased 56, and 58\% $(\mathrm{p}<0.01)$, respectively (Table 4), but there was no significant influence in group I ( $>0.05)$.

\section{Effects of SBL on ADSL mRNA expression in liver in AA broilers}

The regression equation of ADSL gene amplification curve is as follows: $y=-3.2246 x+32.776, R^{2}=0.9972$; the regression equation of 18sRNA gene amplification curve is as follows: $y=-3.2025 x+33.081, R^{2}=0.9976$. The amplification efficiency of the target gene is similar to that of reference gene from amplification efficiency E. The ADSL gene relative expression was expressed as $2^{-\Delta \mathrm{Ct}}$ (Feng, 2007), and its gene relative expression of group I, II and III were significantly increased 80,65 , and $49 \%(\mathrm{p}<0.01)$, respectively, compared to chicks fed basal diet (Table 4).

\section{DISCUSSION}

Heat stress is one of the most universal and predominant factors that restrict the development of poultry in modern

Table 3. Effect on IMP content of breast muscle and thigh muscle ${ }^{1,2}$ unit (mg/g)

\begin{tabular}{lcccccc}
\hline Items & Control & Group I & Group II & Group III & SEM & p \\
\hline breast muscle & $1.65^{\mathrm{c}}$ & $2.77^{\mathrm{b}}$ & $3.34^{\mathrm{a}}$ & $3.35^{\mathrm{a}}$ & 0.078 & $<0.001$ \\
thigh muscle & $1.98^{\mathrm{b}}$ & $2.18^{\mathrm{b}}$ & $2.57^{\mathrm{a}}$ & $2.61^{\mathrm{a}}$ & 0.084 & 0.0012 \\
\hline
\end{tabular}

${ }^{1}$ Values are mean \pm pooled SEM $(n=6) .{ }^{2}$ Means without a common letter differ, $\mathrm{p}<0.01$.

Table 4. Effect of SBL on ADSL mRNA expression ${ }^{1,2}$

\begin{tabular}{llccccc}
\hline Items & Control & Group I & Group II & Group III & SEM & P \\
\hline Liver & $0.0113^{\mathrm{b}}$ & $0.0203^{\mathrm{a}}$ & $0.0186^{\mathrm{a}}$ & $0.0168^{\mathrm{a}}$ & 0.00176 & 0.0050 \\
\hline
\end{tabular}

${ }^{1}$ Values are mean \pm pooled SEM $(n=6) .{ }^{2}$ Means without a common letter differ, $\mathrm{p}<0.01$. 
cultivation facilities. A number of bioactive components have been used to reduce heat stress, including tea polyphenols (Wang, 2004; Liu, 2005), extraction of fructus ligustri lucidi (Zhuang, 2007), Chinese magnoliavine fruit (Ma et al., 2005), lycopene (Sahin et al., 2006), and Turkish propolis (TatliSeven et al., 2007). It has been reported that vitamin $\mathrm{E}$, vitamin $\mathrm{C}$ and flavones also reduce the detrimental effects of heat stress (Sahin et al., 2002a; Sahin et al., 2002b; Chen, 2004; Wang, 2004; Huang, 2005). These are major constituents of sea buckthorn, however, there has been no direct study of the anti-heat stress of sea buckthorn. Heat stress not only decreases poultry performance (Chiang et al., 2008), but also the meat flavor. Meat flavor is influenced by flavor precursors, including amino acids, carbohydrates, inorganic salts and nucleotides. ATP is the major nucleotide in living muscle, however, during rigor mortis, it is converted into IMP. IMP is thought to be one of the most important factors in flavor development as it is a source of reducing sugar and nitrogenous base for Maillard reactions and acts as a flavor enhancer (Bayliss et al., 1995). Herein, SBL as a feed additive decreased the damage to meat flavor by increasing the muscle IMP content, but the interaction between IMP and other meat flavor precursors and its organoleptic properties remains to be determined.

One of the mechanisms of action whereby SBL increased IMP content was investigated. ADSL is an important enzyme that catalyzes two similar reactions in the de novo purine biosynthesis pathway. It catalyses the conversion of succinylaminoimidazole carboxamide ribotide (SAICAR) to aminoimidazole carboxamide ribotide (AICAR), as well as, the formation of adenosine monophosphate (AMP) from adenylosuccinate in the purine nucleotide cycle (Kmoch et al., 2000; Toth and Yeates, 2000). The content of IMP in muscle is influenced by $\mathrm{pH}$, temperature and water activity (Vani et al., 2005; Kavitha et al., 2006), however, the background in raw meat is determined by ADSL gene expression (Zhang, 2006). All three SBL levels increased the ADSL gene expression. In a previous study, estrogen significantly increased the transcription rate of the ADSL gene (Zhu et al., 2001). The flavones in sea buckthorn are phytoestrogen that can exert estrogenic or anti-estrogenic actions depending on concentration, so it is possible that the SBL increased the ADSL gene expression in liver via its estrogenic activity. Generally, the SBL increased muscle IMP content by increasing ADSL gene expression, but the basal diet supplemented with $0.25 \%$ SBL didn't increase the IMP content of thigh muscle although it increased ADSL gene expression, implying that dosage is an important factor. In addition, Kavitha and Modi (2006) found that the IMP content of fresh breast muscle was higher than that of fresh thigh muscle, suggesting that the synthesis of IMP in the breast muscle was different from thigh muscle maybe or that other ingredients of SBL played a role in part in the deposition of IMP. There are currently no data on the effect of SBL and the underlying mechanism of its action. In light of these results, future studies will evaluate the other mechanisms of SBL involved in improving meat flavor during regular temperature and heat stress.

In a summary, a basal diet supplemented with SBL increased muscle IMP content of AA broilers compared with the control, thereby, decreased the loss of meat flavor substance caused by heat stress. The likelihood was that SBL played a part in improving meat flavor during heat stress in AA broilers via enhancing the ADSL gene expression in livers.

\section{ACKNOWLEDGEMENTS}

The investigation was supported by the Special Fund for Technological Innovation Talents of Harbin Science and Technology Bureau (2011RFLXN015), the Program for Backbone Teachers Innovation Ability of Heilongjiang Province (1152G008), and the Program for Innovative Research Team of Northeast Agricultural University (IRTNEAU, CXT006-2-1).

\section{REFERENCES}

Bayliss, P. 1995. Chemistry in the kitchen: the chemistry of flesh foods III. Nutr. Food Sci. 95:23-28.

Bekker, N. P. and A. I. Giushenkova. 1997. Neutral lipids of the bark of Hippophae rhamnoides branches. Chem. Nat. Compd. 29:493.

Boivin, D., M. Blanchette, S. Barrette, A. Moghrabi and R. Béliveau. 2007. Inhibition of cancer cell proliferation and suppression of TNF-induced activation of NFkappaB by edible berry juice. Anticancer Res. 27:937-948.

Chawla, R., R. Arora, S. Singh, R. K. Sagar, R. K. Sharma, R. Kumar, A. Sharma, M. L. Gupta, S. Singh, J. Prasad, H. A. Khan, A. Swaroop, A. K. Sinha, A. K. Gupta, R. P. Tripathi and P. S. Ahuja. 2007. Radioprotective and antioxidant activity of fractionated extracts of berries of Hippophae rhamnoides. J. Med. Food. 10:101-109.

Chen, R. G., R. Lochmann, A. Goodwin, K. Praveen, K. Dabrowski and K. J. Lee. 2004. Effects of dietary vitamin C and $\mathrm{E}$ on alternative complement activity, hematology, tissue composition, vitamin concentrations and response to heat stress in juvenile golden shiner (Notemigonus crysoleucas). Aquaculture 242:553-569.

Chiang, W., A. Booren and G. Strasburg. 2008. The effect of heat stress on thyroid hormone response and meat quality in turkeys of two genetic lines. Meat Sci. 80:615-622.

Dorhoi, A., V. Dobrean, M. Zăhan and P. Virag. 2006. Modulatory effects of several herbal extracts on avian peripheral blood cell immune responses. Phytother. Res. 20:352-358.

Feng, Y. M. 2007. Effects of excessive vitamin A on calcium and phosphorous metabolism in broilers and underlying 
mechanisms. Ph. D. Thesis, Inner Mongolia Agricultural University, Hohhot, Inner Mongolia.

Gao, Z. L., X. H. Gu, F. T. Cheng and F. H. Jiang. 2003. Effect of sea buckthorn on liver fibrosis: a clinical study. World J. Gastroenterol. 9:1615-1617.

Geetha, S., M. Sai Ram, S. K. Sharma, G. Ilavazhagan, P. K. Banerjee and R. C. Sawhney. 2009. Cytoprotective and antioxidant activity of seabuckthorn (Hippophae rhamnoides L.) flavones against tert-butyl hydroperoxide-induced cytotoxicity in lymphocytes. J. Med. Food. 12:151-158.

Geetha, S., M. Sai Ram, V. Singh, G. Ilavazhagan and R. C. Sawhney. 2002a. Anti-oxidant and immunomodulatory properties of seabuckthorn (Hippophae rhamnoides)-an in vitro study. J. Ethnopharmacol. 79:373-378.

Geetha, S., M. Sai Ram, V. Singh, G. Ilavazhagan and R. C Sawhney. 2002b. Effect of seabuckthorn on sodium nitroprusside-induced cytotoxicity in murine macrophages. Biomed. Pharmacother. 56:463-467.

Goncharova, N. P. and A. I. Glushenkova. 1993. Lipids of the leaves of Central Asian forms of sea buckthorn. Chem. Nat. Compd. 33:797-798.

Gregory, N. G. 2010. How climatic changes could affect meat quality. Food Res. Int. 43:1866-1873.

Häkkinen, S. H., S. O. Kärenlampi, I. M. Heinonen, H. M. Mykkänen and A. R. Törrönen. 1999. Content of the flavonols quercetin, myricetin, and kaempferol in 25 edible berries. $\mathrm{J}$. Agric. Food Chem. 47: 2274-2279.

Huang, J. M., G. L. Wang, Z. B. Liu and L. J. Zhang. 2006. Effect of daidzein on testicle development, sperm quality and serum thyroid hormone of cock under acute heat-stress condition. Reprod. Phys. 42:23-25.

Kavitha, S. and V. K. Modi. 2006. Effect of water activity and temperature on degradation of 5 '-inosine monophosphate in a meat model system. LWT-Food. Sci. Tech. 40:1280-1286.

Kmoch, S., H. Hartmannová, B. Stibùrková, J. Krijt, M. Zikánová and I. Śebesta. 2000. Human adenylosuccinate lyase (ADSL), cloning and characterization of full-length cDNA and its isoform, gene structure and molecular basis for ADSL deficiency in six patients. Hum. Mol. Genet. 9:1501-1513.

Krylova, S. G., O. N. Konovalova and E. P. Zueva. 2000. Correction by common sea buckthorn bark and sprout extracts of hormonal and metabolic disturbances during stress in rats. Eksp. Klin. Farmakol. 63:70-73.

Kudritskaya, S. E., L. M. Zagorodskaya and E. E. Shishkina. 1989. Carotenoids of the sea buckthorn, variety Obil'naya. Chem. Nat. Compd. 25:724-725.

Larmo, P., J. Alin, E. Salminen, H. Kallio and R. Tahvonen. 2008. Effects of sea buckthorn berries on infections and inflammation: a double-blind, randomized, placebo-controlled trial. Eur. J. Clin. Nutr. 62: 1123-1130.

Liu, H. J. 2005. Eeffct of TEA Poly Phenols and Daidein broilers under heat-stress condition. Master's Thesis, Northeast Agricultural University, Harbin, Heilongjiang.

Liu M. 2011. Effects of acute heat stress on growth performance and lipid metabolism of broilers. Chinese Journal of Animal Nutrition. 2011, 23:862-868.

Luhua, Z., T. Ying, Z. Zhengyu and W. Guangji. 2004. Determination of alpha-tocopherol in the Traditional Chinese Medicinal preparation Sea buckthorn oil capsule by non- aqueous reversed phase-HPLC. Chem. Pharm. Bull. (Tokyo). 52:150-152.

Lu, Q. P., J. Wen, H. F. Zhang, Y. W. Dong and Q. J. Wang. 2009. Effects of high ambient temperature on meat quality and flavor in commercial and local broilers. Acta Veterinaria et Zootechnica Sinica. 40:203-207.

Ma, D. Y., A. S. Shan and Z. H. Chen. 2005. Influence of Ligustrum Lucidum, Schisandra Chinensis, Si Jun Zi Tang and Daidzein on Antioxidant Staus of Laying Hens Under Heat Stress. Acta. Zoonutrimenta. Sinica. 17:23-27.

Ma, G., C. L. Yang, Y. Qu, H. Y. Wei, T. T. Zhang and N. J. Zhang. 2007. The flavonoid component isorhamnetin in vitro inhibits proliferation and induces apoptosis in Eca-109 cells. Chem. Biol. Interact. 167:153-160.

Matsubara, Y., K. Sato, H. Ishii and Y. Akiba. 2005. Changes in mRNA expression of regulatory factors involved in adipocyte differentiation during fatty acid induced adipogenesis in chicken. Comp. Biochem. Phys A. 141:108-115.

Melesse, A., S. Maak, R. Schmidt and G. von Lengerken. 2011. Effect of long-term heat stress on some performance traits and plasma enzyme activities in Naked-neck chickens and their F1 crosses with commercial layer breeds. Livest. Sci.

Miao, Y. 2007. Effects of acute heat stress on meat quality and peroxidation in broilers fed different sources of fat. Master's Thesis, Chinese Aeademy of Agricultural Sciences, Beijing.

NY/T 33-2004 (Agriculture Standard of The People's Republic of China). 2004. Feeding standard of chicken. Ministry of Agriculture of The People's Republic of China, Beijing.

National Research Council. 1994. Nutrient requirements of poultry. 9th Ed. National Academy Press, Washington, DC.

Olsson, M. E., K. E. Gustavsson, S. Andersson, A. Nilsson and R. D. Duan. 2004. Inhibition of cancer cell proliferation in vitro by fruit and berry extracts and correlations with antioxidant levels. J. Agric. Food Chem. 52: 7264-7271.

Püssa, T., R. Pällin, P. Raudsepp, R. Soidla and M. Rei. 2007. Inhibition of lipid oxidation and dynamics of polyphenol content in mechanically deboned meat supplemented with sea buckthorn (Hippophae rhamnoides) berry residues. Food Chem. 107:714-721.

Ranjith, A., K. SarinKumar, V. V. Venugopalan, C. Arumughan, R. C. Sawhney and Singh Virendra. 2006. Fatty acids, tocols, and carotenoids in pulp oil of three sea buckthorn species (Hippophae rhamnoides, $H$. salicifolia, and $H$. tibetana) grown in the Indian himalayas. J. Am. Oil. Chem. 83: 359-364.

Repyakh, S. M., A. P. Kargapol'tsev, N. A. Chuprova and G. G. Yushipitsina. 1990. Amino acid composition and biological value of proteins of the woody verdure of sea buckthorn. Chem. Nat. Compd. 26:110-111.

Saggu, S. and R. Kumar. 2007. Possible mechanism of adaptogenic activity of seabuckthorn (Hippophae rhamnoides) during exposure to cold, hypoxia and restraint (C-H-R) stress induced hypothermia and post stress recovery in rats. Food Chem. Toxicol. 45:2426-2433.

Sahin, K., M. Ondercib, N. Sahinb, M. F. Gursuc, F. Khachikd and O. Kucuke. 2006. Effects of lycopene supplementation on antioxidant status, oxidative stress, performance and carcass characteristics in heat-stressed Japanese quail. J. Therm. Biol. 31:307-312.

Sahin, K., N. Sahin and M. Onderci. 2002a. 
supplementation can alleviate negative effects of heat stress on egg production, egg quality, digestibility of nutrients and egg yolk mineral concentrations of Japanese quails. Res. Vet. Sci. 73:307-312.

Sahin, K., N. Sahin, M. San and M. F. Gursu. 2002b. Effects of vitamins $\mathrm{E}$ and $\mathrm{A}$ supplementation on lipid peroxidation and concentration of some mineral in broilers reared under heat stress $\left(32^{\circ} \mathrm{C}\right)$. Nutr. Res. 22:723-731.

TatliSeven, P., I. Seven, M. Yilmaz and Ü. G. Simşek. 2007. The effects of Turkish propolis on growth and carcass characteristics in broilers under heat stress. Anim. Feed Sci. Technol. 146:137-148.

Toth, E. A. and T. O. Yeates. 2000. The structure of adenylosuccinate lyase, an enzyme with dual activity in the de novo purine biosynthetic pathway. Structure 8:163-174.

Ul'chenko, N. T., T. G. Zhmyrko, A. I. Glushenkova and Y. M. Murdakhaev. 1995. Lipids of Hippophae rhamnoides pericarp. Chem. Nat. Compd. 31:565-567.

Vani, N. D., V. K. Modi, S. Kavitha, N. M. Sachindra and N. S. Mahendrakar. 2005. Degradation of inosine-5'-monophosphate (IMP) in aqueous and in layering chicken muscle fibre systems: Effect of $\mathrm{pH}$ and temperature. LWT-Food Sci. Technol. 39:627-632.
Wang, Y. Q. 2004. Eeffet of tea polyphenols and vitamin E on borilers performance and antioxygen on under heat-srtess condtions. Master's Thesis, Northeast Agricultural University, Harbin, Heilongjiang.

Yang, B. 2009. Sugars, acids, ethyl $\beta$-D-glucopyranose and a methyl inositol in sea buckthorn (Hippophae rhamnoides) berries. Food. Chem. 112:9-97.

Yushipitsina, G. G., N. A. Chuprova and S. M. Repyakh. 1988. Fractionation and amino acid compositon of proteins of the woody verdure of sea buckthorn. Chem. Nat. Compd. 24:348350.

Zadernowski, R., M. Naczk and R. Amarowicz. 2003. Tocopherols in sea buckthorn (hippophaë rhamnoides 1.) Berry oil. J. Am. Oil. Chem. Soc. 80:55-58.

Zhang, X. Y., C. L. Ji, G. H. Chen, J. Qin, J. T. Shu and Y. J. Su. 2006. The diversity of adenylosuccinate lyase (Ads1) gene and its relationship with Inosinic acid content in chicken. J. Yunnan. Agr. Univ. 21: 231-234.

Zhu, Y. F., M. Wang, H. Lin, Z. Li and J. Luo. 2001. Identification of estrogen-responsive genes in chick liver. Cell. Tissue Res. 305:357-363.

Zhuang, B. F. 2007. Influence of extraction of fruetus ligustri lueidi on meat quality and incretion status of broilers under heat stress. Master's Thesis, Northeast Agricultural University, Harbin, Heilongjiang. 